\title{
Maintenance Technician is Struck by Crane, Falls 10 feet to Conveyor and Dies
}

\section{CASE SUMMARY}

On Monday, January 26, 2015 a maintenance technician was working from an elevated platform and leaned through a railing on the west side of the upright I-beam to clear a jam and to change a micro switch while the overhead crane system was active. The victim's back was towards the crane system as he worked. While the victim attempted to change the micro switch, the crane struck the victim's right hand resting on top of the I- beam, causing him to fall $10 \mathrm{ft}$ and land on the conveyor system below.

A maintenance technician on the floor saw the victim fall, and alerted in-house medically trained employees. The first response team assessed the victim while a call was placed for an ambulance at 8:54 pm. The ambulance arrived at 9:04 pm and transported the victim to the local hospital. The victim died in transit from multiple blunt force injuries and mechanical asphyxia sustained in a fall from height. Time of death was 9:41pm.

\section{Recommendations for prevention:}

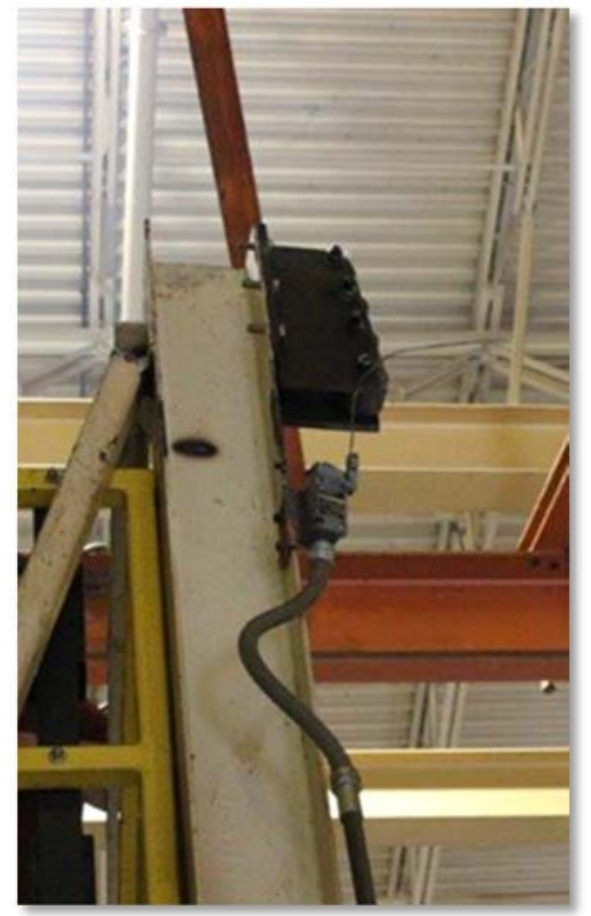

Figure 1. Micro switch the victim was repairing at the time of the incident.

- Employers should ensure that employees are following lock out/tag out policies at all times.

- Employers should ensure that fall protection is worn when working at heights on equipment.

- Employers should ensure that all walk areas four feet or higher are guarded by railings on all sides.

- A pre-hazard job analysis should be done before beginning work. 


\section{EMPLOYER}

The employer was an auto/truck parts manufacturer who specialized in truck and auto framework and part manufacturing. The company had been in business since 2004 and has 1,200 employees.

\section{SAFETY AND TRAINING PROGRAMS}

The employer had written safety policies and employee training. Employees are trained annually on lock out tag out, it was discovered during the employee interview process that the lock out tag out policy was not enforced or applied to the overhead crane when employees were in the area working on conveyors or resetting buttons. Employees did receive annual refresher lock out tag out training.

\section{VICTIM}

The victim, a five foot 6 inch tall, 60-year-old high school graduate, was a maintenance technician II who had been with the company for 8 years.

\section{INCIDENT SCENE}

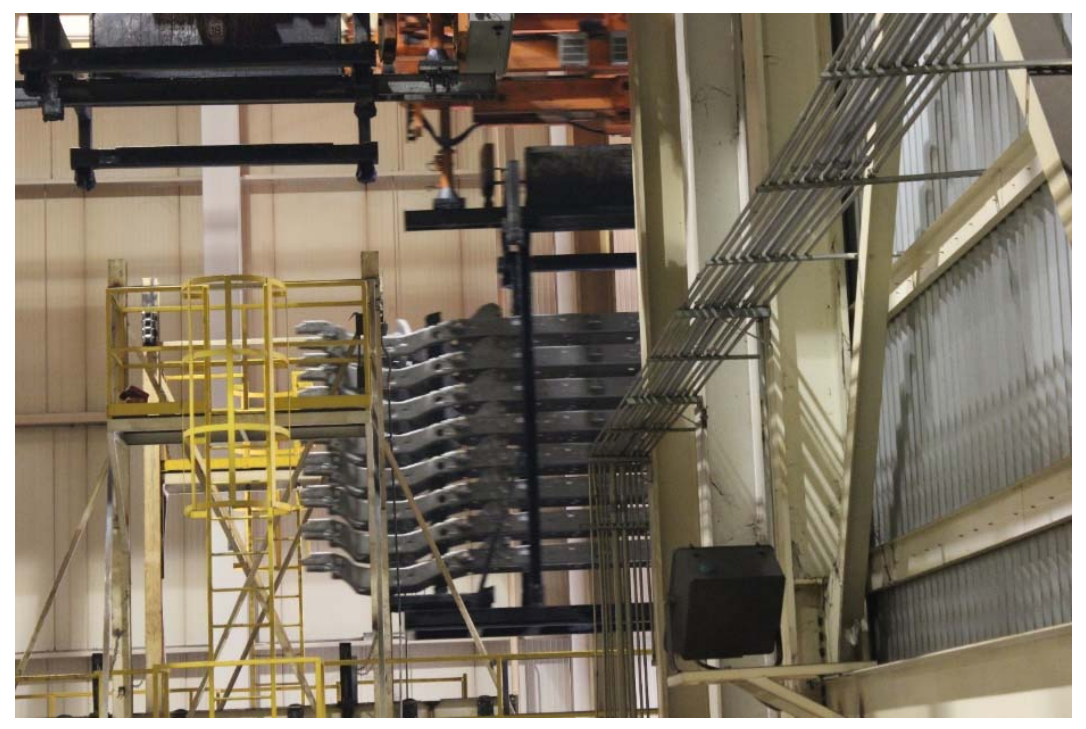

Figure 2. Crow's nest where the worker was standing.

The incident scene was inside a manufacturing facility, on an E-Coat conveyor system located 20 feet from the floor. The victim had been working from an upper level crow's nest which was located 10 feet above the conveyor system. A crane assembly system passed less than $6 \mathrm{ft}$ above the crow's nest walking surface.

\section{WEATHER}


January 26, 2015, was an overcast day with temperatures ranging from 30 to 41 degrees Fahrenheit. Weather was not considered to be a factor in this fatality

\section{INVESTIGATION}

The Kentucky Labor Cabinet notified the Kentucky Fatality Assessment and Control Evaluation Program (FACE) of a fatality involving a fall from a platform to another level. An investigation was conducted.

On Monday, January 26, 2015, a second shift maintenance technician climbed up the attached metal ladder to the crow's nest, that was situated 10 feet above a conveyor system (see figure 2). The conveyor system was located 20 feet above the ground level (see figure 3B). Just 6 feet above the crow's nest was a crane assembly system which had not been disengaged (see 3A). It was typical for the maintenance technicians to access this area more than four times per shift to clear jams in the production pathway or make repairs as needed. It is believed the victim was leaning over the railing of the crow's nest to change out a micro switch while holding onto the I-beam with his right hand (see figure 4A). While the victim worked on the switch, the overhead crane system which was still running came into contact with his right hand, causing him to lose his balance and fall 10 feet landing on the conveyor below (see figure 4B).
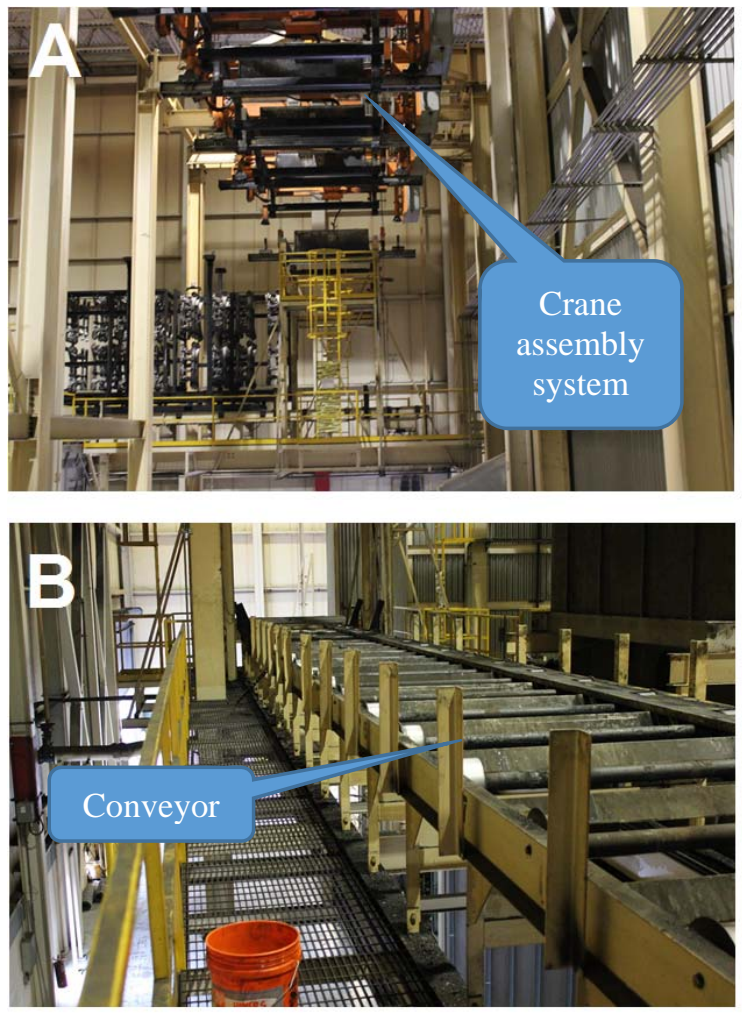

Figure 3. A) Overhead crane assembly system. B) Conveyor that was beneath the crow's nest.

A maintenance worker who was on the ground floor saw the victim fall and immediately notified the company's in-house medically trained employees to assist the victim. The first responders called for an ambulance at 8:54 pm and assisted the victim. They
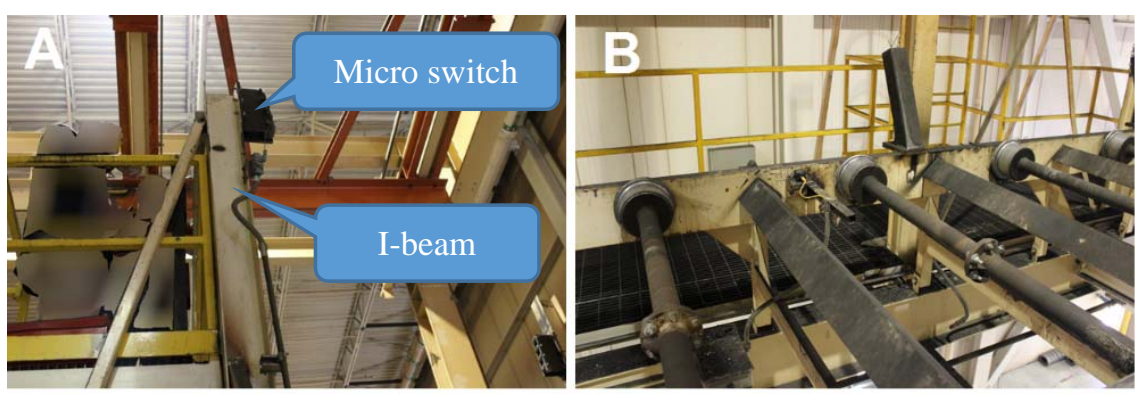

Figure 4. A) Micro switch being repaired and I-beam victim was holding on to. B) Area of conveyor belt where victim fell. 
placed the victim on a back board to lower him to the ground level. First responders performed CPR until the ambulance arrived at 9:04 pm. The victim was transported to the nearest hospital. The victim died in transit and was pronounced dead at 9:41pm.

The investigation revealed the company had a written lock-out/tag-out program. During interviews with the maintenance technicians, they stated they never locked-out or tagged-out to perform the task the victim was performing. The standard procedure was to fix the jam or replace the part while the crane was operating. Occasionally a request was made to stop the crane and conveyor, but it was not locked-out or tagged-out.

\section{CAUSE OF DEATH}

The cause of death was multiple blunt force injuries and mechanical asphyxia sustained in a fall from height

\section{CONTRIBUTING FACTORS}

Occupational injuries and fatalities are often the result of one or more contributing factors that ultimately result in injury or death. The investigation identified the following factors that may have contributed to the fatality:

- Enforcement and use of lock out tag out policy

- Lack of use of fall protection

\section{RECOMMENDATIONS AND DISCUSSIONS}

\section{Recommendation No. 1: Employers should ensure that employees are following lockout/ tag} out policies at all times. ${ }^{1}$

OSHA standard 29 CFR 1910.147 addresses the practices and procedures necessary to disable equipment or machinery, preventing the release of hazardous energy while employees perform maintenance work. By locking-out the equipment, there is no possibility of accidental engagement of equipment while maintenance activities are performed

\section{Recommendation No. 2: Employers should ensure that fall protection is worn when} working at heights on equipment. ${ }^{2}$

The employee may have been protected from the ensuing fatal fall, had he worn fall protection.

Recommendation No. 3: Employers should ensure that all walk areas four feet or higher are guarded by railings on all sides. ${ }^{3}$ 
The catwalk along the upper conveyor system did not have end railings on the north end of the catwalk. OSHA regulation 29 CFR 1910.23 states that all walking-working surfaces must be guarded by standard railings on all exposed sides. Guard railings would prevent an employee from being exposed to a fall hazard.

Recommendation No. 4: A pre-hazard job analysis should be done before beginning work.

A pre-hazard job analysis would have made the employee aware of the hazards he was exposed to while working in the area, and alert him to his surroundings. Specific to this case, an assessment of the working area would have identified the risk of the passing overhead crane system to the worker.

Please take the time to complete our brief survey regarding this report:

(https://uky.az1.qualtrics.com/jfe/form/SV_7NSZ3BEU8uC7X8x)

Electronic access to this full report can be found here:

(http://www.mc.uky.edu/kiprc/programs/face/files/15KY011.pdf)

\section{KEYWORDS}

Fall protection

Working from heights

Lockout/ Tagout

\section{REFERENCES}

129 CFR 1910.147 The Control of Hazardous Energy (Lockout/Tagout), Title 29. United States Department of Labor. [https://www.osha.gov/OshDoc/data_General_Facts/factsheet-lockout-tagou.pdf]

229 CFR 1910 Standards and Policy for Non-Construction Work. United States Department of Labor [https://www.osha.gov/SLTC/fallprotection/standards.html]

329 CFR 1910.23 Guarding floor and wall openings and holes. United States Department of Labor.

[https://www.osha.gov/pls/oshaweb/owadisp.show_document?p_table=STANDARDS\&p_id=97

15]

\section{PHOTO CREDIT}

All photo credit goes to Kentucky OSH. 


\section{ACKNOWLEDGEMENTS}

The Kentucky FACE program would like to thank the coroner and Kentucky OSHA for their assistance with this report

\section{PROGRAM FUNDING}

The Kentucky Fatality Assessment \& Control Evaluation Program (FACE) is funded by grant 2U60OH008483-11 from the Centers for Disease Control and Prevention and the National Institute for Occupational Safety and Health.

\section{FACE on Social Media:}

https://www.facebook.com/Kentucky-FACE-Program$\underline{134135740092906 / \text { ?view_public_for }=134135740092906}$

\section{http://www.twitter.com/KYFACEProgram}

This case report was developed by the Kentucky Fatality Assessment and Control Evaluation (FACE) Program. Kentucky FACE is a NIOSH-funded occupational fatality surveillance program with a goal of preventing fatal work injuries by studying the worker, the work environment, and the role of management, engineering, and behavioral changes in preventing future injuries. The FACE Program is located within the Kentucky Injury Prevention and Research Center (KIPRC), part of the University of Kentucky's College of Public Health.

Email: kyfaceprogram@uky.edu | Telephone: 859-257-5839 333 Waller Avenue Suite 242, Lexington, KY 40504 